\title{
Olga Białek-Szwed
}

ORCID: 0000-0001-5702-4458

Katolicki Uniwersytet Lubelski Jana Pawła II w Lublinie

o.bialek.szwed@wp.pl

DOI: $10.35765 /$ pk.2019.2401.09

\section{Przemiany społeczno-kulturowe XXI wieku a poczucie braku stabilizacji - perspektywa medioznawcza}

\section{STRESZCZENIE}

W artykule autorka próbuje zaprezentować korelacje zachodzące pomiędzy współczesnymi przemianami cywilizacyjno-kulturowymi a sytuacją człowieka - konsumenta mediów XXI w. Przeprowadzone analizy dokonuje z perspektywy badacza współczesnych mediów masowych. Jej celem jest przedstawienie i opisanie pewnego wycinka badań medioznawczych, które ukazują specyfikę niektórych mechanizmów rządzących współczesnymi mediami, takich jak np. voyeuryzm medialny, tzw. living on line czy metafora synopticonu. Oczywiście nie ma miejsca w niniejszym artykule na szczegółową analizę wyliczonych mechanizmów, ale warto wiedzieć, że przykładowo dominujący wśród nich voyeuryzm obecny jest w zachowaniach społecznych i w mediach (kiedyś tylko w mediach drukowanych) od stuleci. Współcześnie dzięki dynamicznemu rozwojowi technologii, nowym mediom, zainteresowaniom odbiorców i nadawców zyskał zupełnie nowe, bezkompromisowe, niejednokrotnie brutalne oblicze.

SŁOWA KLUCZE: voyeuryzm medialny, współczesne media, wizualizacja mediów 


\section{AB STRACT}

\section{Social and Cultural Transformations of the 21st Century and} the Feeling of Lack of Stabilization - a Media Studies Perspectives

In the article, the author tries to present correlations between contemporary civilizational and cultural changes and the human situation the media consumer of the 21 st century. The analyzes carried out are made from the perspective of the researcher of contemporary mass media. Its aim is to present and describe a certain section of media studies that show the specificity of some of the mechanisms governing modern media, such as media voyeurism, the so-called living on line, or synopticon metaphor. Of course, there is no place in this article for a detailed analysis of the calculated mechanisms, but it is worth knowing that, for example, the dominant voyeurism among them, is present in social behavior and in the media (once only in printed media) for centuries. Today, thanks to the dynamic development of technology, new media, interests of recipients and broadcasters, he has gained a completely new, uncompromising, often brutal face.

KEYWORDS: media voyeurism, contemporary media, media visualization

Wiek XXI przyniósł awangardowe sposoby tworzenia oraz percepcji produktów kultury, mediów czy też techniki. Nowatorskim mechanizmom, wynikającym między innymi z przemian społeczno-kulturowych (np. laicyzacji życia, zaniku rodzin wielopokoleniowych i zwartych wspólnot lokalnych), zaczęły towarzyszyć zmiany w mentalności człowieka, sposobie spędzania czasu wolnego, planowania swojej przyszłości.

Zdaniem antropologa kultury, Rocha Sulimy, jednym z poważniejszych problemów współczesności jest brak poczucia stabilizacji. Jej przyczyn Sulima doszukiwał się w rozluźnieniu zasad moralnych, większej swobodzie obyczajowej oraz w dynamicznym rozwoju techniki umożliwiającym przyglądanie się sprawom prywatnym, a nawet intymnym drugiego człowieka ${ }^{1}$. Niezastąpionym narzędziem, sprzyjającym stałemu

1 Psychologowie Bogdan Wojciszke i Wiesław Baryła badali konsekwencje wpływu na człowieka XXI w. trzech czynników: psychologicznego, socjologicznego i technicznego, które ich zdaniem mają decydować o braku poczucia stabilizacji. Czynnik psychologiczny ma determinować pragnienie przynależności do grupy. Czynnik społeczny odpowiada za rozpad tradycyjnych form egzystencji, czyli dezintegrację społeczności lokalnych, na co ma mieć wpływ mobilność, która skutkuje powierzchownością i tymczasowością relacji społecznych. Czynnik 
penetrowaniu życia prywatnego innych ludzi, są nowe media, ze wskazaniem na globalną sieć Internet ${ }^{2}$. Według psychologów, Bogdana Wojciszke i Wiesława Baryły - Internet, ale też i inne, bardziej tradycyjne, choć równie voyeurystycznie nastawione media, mają za zadanie zaspokajanie potrzeb przynależności, o którą w XXI w. wcale nie jest łatwo ${ }^{3}$. Tymczasowość relacji, nieustanna mobilność współczesnego człowieka, oderwanie się od korzeni utrudnia uzyskanie poczucia stabilizacji.

\section{Współczesny człowiek - „nomadem XXI w.”}

Paradygmatem współczesności stał się podróżnik, „nomad XXI w.”, który jawi się w dwóch wcieleniach - turysty i włóczęgi. Jak zauważał Zygmunt Bauman, oba wcielenia wiele łączy, ale jeszcze więcej dzieli. Zarówno dla włóczęgi, jak i turysty permanentna migracja staje się nieodłącznym elementem życia. Obaj podróżują do coraz to nowszych miejsc, do żadnego się nie przyzwyczajają, nigdzie nie starają się „zapuścić korzeni”, wszędzie są tylko przejazdem, wszędzie są tylko gośćmi. Nigdy nie czują się, że są „u siebie”, a podróżowanie to dla nich wartość podstawowa, z tą tylko różnicą, że dla turysty jest ono wyznacznikiem wolności, a dla włóczęgi uciążliwym brakiem stabilizacji. Zygmunt Bauman nazywa włóczęgę „mutantem ponowoczesnej ewolucji” lub „brakiem produkcyjnym zalegającym fabryczne place” w świecie będącym wytwórnią turystów ${ }^{4}$.

Toposy: turysty i włóczęgi można traktować jako współczesne metafory życia człowieka XXI w., który nie przykłada wagi do posiadanych rzeczy; zmienia mieszkania, pracę, partnera, przyjaciół. Oddalając się zaś od tradycyjnych zachowań społecznych, obniża swoje poczucie bezpieczeństwa. Zdaniem profesora Ricardo Petrella z Katolickiego Uniwersytetu w Louvain sposób bycia współczesnego człowieka, zdeterminowanego wieczną migracją, obrazują dzisiejsze produkty konsumpcyjne oraz wszelkiego rodzaju usługi, które charakteryzuje krótki termin przydatności. Aktualnie zdecydowanie częściej kupuje się nowy produkt, niż naprawia używany, niezależnie czy jest to obuwie, mebel, sprzęt AGD i RTV, komputer ${ }^{5}$.

techniczny, poprzez system kamer, oferuje stały dostęp do przekazów treści - zdjęć i filmów. Por. B. Wojciszke, B. Baryła, Podglądanie zamiast, przed i po, „Charaktery” 2001, nr 5, s. 12-18.

2 Por. R. Sulima, Oko Wielkiego Brata, w: Podgląd Wielkiego Brata, red. W. Godzic, Kraków 2001, s. 31-32.

3 Por. B. Wojciszke, B. Baryła, Podgladanie zamiast, przed i po, dz. cyt., s. 18.

4 Por. Z. Bauman, Ponowoczesność jako źródto cierpień, Warszawa 2000, s. 61.

5 Por. Z. Bauman, Globalizacja, Warszawa 2000, s. 93. 
Paradygmat wyobcowanego turysty nawiązuje do XIX-wiecznego toposu włóczęgi po metropolii, tzw. le flâneur ${ }^{6}$, który utożsamiany był z osobą najlepiej czującą się w wielkomiejskim tłumie, a jego podstawowym zajęciem było przemierzanie wielkich przestrzeni nowoczesnego miasta.

Flanera pociągały chaos na ulicach, liczne sklepy i ich kolorowe wystawy, anonimowi przechodnie, którym uwielbiał się przyglądać. Z tego powodu flâneur kojarzony był też ze spiskowcem, detektywem, amatorem mrocznych tajemnic miasta, agentem służb specjalnych, fotografem, dandysem, a nawet prostytutką. Flâneura opisywano w różny sposób, najczęściej był on wyposażony w nieodłączny zestaw rekwizytów, takich jak: gazeta codzienna, którą czytał nie dla doniesień na temat wydarzeń rangi państwowej, ale dla plotek. Współcześnie nie raz zastanawiano się, czy XIX-wieczny topos flâneura przetrwał, dotrwał do XXI wieku. Ci, którzy opowiadają się za jego nieprzerwaną egzystencją, zwracają uwagę na klientów wielkich galerii handlowych, którzy potrafią wiele godzin spacerować i podglądać innych ludzi. W ocenie kulturoznawców i antropologów współczesne galerie handlowe zastąpiły dawne wielkomiejskie centra rozrywki i handlu. Dzisiejszy flâneur bywa również określany jako postflâneur ${ }^{7}$.

Kulturoznawcy posługują się toposem le flâneur przy rozpatrywaniu wizualnego wymiaru życia w mieście. Koncepcja le flâneur jak najbardziej wpisuje się w schemat współczesnego, samotnego wędrowca, dla którego bardzo ważne są ulotne doznania wzrokowe. To one zapełniają pustkę, którą wcześniej wypełniały spotkania z bliskimi, rozmowy, praca związana z podtrzymywaniem więzów z rodziną i przyjaciółmi. Współczesny „nomad”, by zapełnić pustkę, sięga po informacje i obrazy związane z życiem osób znanych z mediów. Przejmuje się ich problemami, bywa, że w mediach (szczególnie społecznościowych) stara się udzielać rad, pomagać,

6 Topos znany pod nazwą flâneur (z fr. „szlifobruk”, wałęsający się w tłumie, spacerowicz) był popularny w XIX w. Termin flâneur został zaakceptowany przez Académie Française w 1879 r., do tego momentu funkcjonował jako zwrot francuskiego slangu. Źródłem debaty nad zjawiskiem oraz mitem miejskim określanym właśnie jako flâneur był przede wszystkim esej Charlesa Baudelaira z 1863 r. pt. Malarz życia nowoczesnego oraz Pasaże Waltera Benjamina (1927), Cztowiek ttumu Edgara Allana Poe (1840), rozmyślania La paysan de Paris Luisa Aragona (1926). Zob. A. Aldridge, Konsumpcja, Warszawa 2006, s. 115-222; T. Miczka, Kultura w stylu KISS. Pierwsze, czyli proste - Keep it Simple, stupie!, „Nowe Media - Nowe w Mediach” 2005, t. I, s. 87-95; S. Morawski, Obraz kultury na przetomie wieków, w: Postmodernizm, red. M.A. Potocka, Kraków 2003, s. 245-259; Z. Kloch, Odmiany dyskursu. Semiotyka życia publicznego po 1989 roku, Wrocław 2006, s. 211.

7 O. Białek-Szwed, Voyeuryzm medialny w kontekście wspótczesnej prasy w Polsce, Toruń 2012, s. 66-67. 
jednocześnie nie angażując się w kłopoty swoich bliskich. W ten oto sposób odbiorca mediów XXI wieku perypetiami bohaterów prasy, radia, telewizji, Internetu zastępuje więzy rodzinne, które na skutek przemian właśnie społeczno-kulturowych ulegają degradacji, są coraz trudniejsze do podtrzymania. Taki stan rzeczy potwierdza chociażby coraz większa liczba rozwodów, stanów depresyjnych, zaburzeń psychosomatycznych.

\section{Media substytutem relacji interpersonalnych}

Anomię więzi rodzinnych badała m.in. profesor Małgorzata Szpakowska. Badaczka oparła się na dość intrygującym materiale, tj. na listach czytelników, przede wszystkim czytelniczek do redakcji prasowych. Wnioski, jakie sformułowała na podstawie swojej pracy, nie napawają optymizmem. Profesor Szpakowska uznała, że współcześni ludzie wolą zgłębiać troski niespokrewnionych, nieznanych sobie osób, a co więcej zainteresowanie cudzymi problemami - jej zdaniem - zastępuje coraz częściej klasyczną komunikację interpersonalną ${ }^{8}$. To, w jaki sposób media zastępują kontakt z „prawdziwym” człowiekiem, starał się pokazać publicysta Mariusz Czubaj. Na łamach tygodnika „Polityka” opisywał fikcyjny świat, quasi-rozmowy, odrealnione problemy, które media proponują swoim odbiorcom. Starał się on również wychwycić i zdiagnozować sytuacje niesprzyjające klasycznej komunikacji interpersonalnej i co za tym idzie pogłębiające poczucie braku stabilizacji i samotności pojedynczego człowieka. Udowadniał, że to, co często współcześni ludzie przyjmują za kontakt bezpośredni pomiędzy dwoma interlokutorami, w rzeczywistości jest tylko czymś pozornym i chwilowym, banalnym w swojej treści. Podstawowym utrudnieniem w prowadzeniu wartościowej komunikacji bezpośredniej - zdaniem Czubaja - jest pogłębiająca się anonimowość, wynikająca z migracji, częstych zmian pracy i miejsca zamieszkania, towarzystwa. Współczesny człowiek jest więc reprezentantem środowiska informacyjnego i wirtualnego. A jak twierdził inny publicysta, Ryszard Kluszczyński -

[Jesteśmy - przyp. O.B.S.] nomadami cyberprzestrzeni. Nasza pamięć jest dziś kolażem fragmentów odwiedzanych światów. Miejsc, czasów, ludzi, okruchów wydarzeń, ideologii i mitów ${ }^{9}$.

8 Por. J. Kowalska, Nudni i upokorzeni, rozmowa z prof. M. Szpakowską „Gazeta Wyborcza” 2001, nr 65, s. 10-11.

9 R.W. Kluszczyński, Spoteczeństwo informacyjne. Cyberkultura. Sztuka multimediów, Kraków 2001, s. 8 . 
Brak stabilizacji to tylko jeden z efektów przemian społeczno-kulturowych obecnych czasów. Inny to chociażby uzależniająca potrzeba odbiorcy mediów korzystania z różnych form inwigilacji medialnej.

Interesujące, że także wspomniany już Zygmunt Bauman dostrzegał związek pomiędzy poczuciem braku stabilizacji, uzależnieniem od różnych form inwigilacji, której sprzyjają nie tylko media, ale i kamery w przestrzeni publicznej, miniaturowe aparaty fotograficzne, wykorzystywanie dronów do inwigilacji innych osób, a globalizacją, którą to znowuż uznawał za główną przyczynę poczucia braku stabilizacji. Zdaniem Baumana najwięcej odpowiedzialności za poczucie wyalienowania współczesnego człowieka przynosi tzw. living on line (tj. czas spędzany w rzeczywistości wirtualnej), na drugim miejscu sytuował proces ujednolicania gustów konsumentów mediów masowych ${ }^{10}$.

W podobnym tonie co Zygmunt Bauman wypowiadał się też Umberto Eco, który to oskarżał wręcz zglobalizowane media o nieustanne kreowanie rzeczywistości, kształtowanie stylu życia i opinii. Dziennikarze zaś dla Eco to grupa demiurgów współczesnej przestrzeni informacyjnej, nieustannie pracująca nad tworzeniem historii, mających za zadanie podsycanie zainteresowania odbiorcy ${ }^{11}$, czemu sprzyjają wszelkie gatunki z rodzaju ,inwigilacyjnych”, takie jak programy reality w telewizji (np. game show, quiz show, talk show, docu soap), programy z użyciem ukrytej kamery lub mikrofonu, artykuły prasowe i internetowe oparte na podglądaniu drugiego człowieka, jak też na zdjęciach wykonywanych przez profesjonalnych paparazzich ${ }^{12}$ oraz liczne grono ich naśladowców - amatorów posługujących się częściej telefonami komórkowymi niż klasycznym sprzętem fotograficznym. Takich paparazzich amatorów

10 Por. Z. Bauman, Globalizacja, Warszawa 2000, s. 9-10, 29.

11 Por. R. Konik, Eco-Logia kultury masowej. Przewodnik po kulturze masowej w oparciu o estetyke Umberto Eco, Wrocław 2003.

12 Paparazzi -azziego, -azzim, -azzich; ale również uznawana jest wersja oryginalna paparazzo (l. poj.), -azzi, -azzich. Paparazzi to włoski dialektyzm, liczba mnoga rzeczownika paparazzo, który w języku włoskim oznacza brzęczącego, natrętnego i uciążliwego owada (przede wszystkim chodzi o komara). Paparazzi to także nazwisko bohatera - Signor Paparazzo (Pan Paparazzo) - filmu Federica Felliniego pt. Stodkie życie (Dolce Vita) z roku 1960, od którego bierze początek nazwa mutacji profesji fotoreporterskiej. Signor Paparazzo Felliniego był fotografem ulicznym polującym na gwiazdy kina. Osoba określana jako paparazzi to „osoba fotografująca prominentne postaci ze świata polityki, kultury, nauki, arystokracji i dostarczająca zdjęcia prasie bulwarowej za wysokie honoraria. Są to fotografie przedstawiające danych bohaterów w krępujących dla nich sytuacjach”. Zob. Wielki Stownik Ortograficzny PWN, red. E. Polański, Warszawa 2006, s. 549; Stownik terminologii medialnej, red. W. Pisarek, Kraków 2006, s. 143; O. Białek-Szwed, Voyeuryzm, dz. cyt., s. 219-222. 
Zbigniew Bauer ${ }^{13}$ określał mianem snaparazzi, czyli neologizmem będącym zrostem dwóch obcojęzycznych terminów - snapshot i paparazzi. Termin pierwszy w języku angielskim oznacza zdjęcie, właśnie amatorskie, a do tego zrobione przypadkowo. Krakowski medioznawca wskazywał miejsca, w których amator wykonuje swoje zdjęcia, są to sale kinowe, plaże i deptaki w popularnych kurortach, restauracje i modne puby, galerie handlowe itp.

\section{Syndrom „oblężonej twierdzy” a medialny ekshibicjonizm}

Paradoksalnym efektem mediów coraz bardziej wdzierających się w prywatność innego człowieka oraz czytelników, radiosłuchaczy, telewidzów, internautów czekających na oparte na podglądaniu materiały jest postępująca izolacja elit artystycznych, politycznych, biznesowych itp., sprzyjająca wyalienowaniu i poczuciu przez nie braku stabilizacji. Im bardziej media starają się wedrzeć w prywatność powszechnie znanych postaci, tym intensywniej bronią one swojej intymności. Oczywiście poza pewnymi wyjątkami, bohaterami, którzy swoją pozycję społeczną opierają na powszechnej rozpoznawalności i nie widzą niczego niestosownego w nadmiernym obnażaniu własnej prywatności, a nawet intymności. Wśród osób publicznych, szczególnie celebrytów, znajdujemy więc takie postaci, które swoim postępowaniem sankcjonują to, co tradycyjnie uchodzi za moralnie naganne. Niektórzy celebryci dla powszechnej rozpoznawalności decydują się na wiele, tj. np. na publiczne plotkowanie na własny temat, jak też dekonspirowanie elementów własnej biografii, szczególnie tych kontrowersyjnych lub dramatycznych. Są nawet tacy, którzy dla zyskania sławy, bez zbędnych zahamowań potrafią mówić o sobie złe rzeczy, epatować swoimi wadami lub nałogami. Na potrzeby popularności tworzą sztuczne kreacje, przybierają maski. Zdaniem Ervinga Goffmana ${ }^{14}$ takie zabiegi można określić mianem fasady, która według propozycji badacza jest niczym innym jak „szumem medialnym”, umiejętnością kupczenia własną osobą oraz zespołem abstrakcyjnych i stereotypowych oczekiwań, a na pewno nie wiarygodnym obrazem prezentowanej postaci. Agaton Koziński i Michał Zaczyński sugerowali, że za popularnością

13 Por. Z. Bauer, „Twój gtos w twoim domu”: cztery typy tabloidyzacji, referat wygłoszony na konferencji naukowej pt. Oblicza komunikacji. Jezzyk $i$ kultura tabloidów, Wrocław 29-30.06.2009, zorganizowanej przez Uniwersytet Wrocławski.

14 Por. E. Goffman, Cztowiek w teatrze życia codziennego, Warszawa 2000, s. 47-60. 
medialnego ekshibicjonizmu kryje się dominująca pozycja na rynku mediów tabloidowych. Zdaniem Kozińskiego i Zaczyńskiego wśród celebrytów można odnaleźć takie osoby, które od publicznego epatowania swoją prywatnością są wręcz uzależnione ${ }^{15}$. Na podobne, dysfunkcyjne zachowania zwracają uwagę badacze cyberprzestrzeni. Analiza popularnych komunikatorów internetowych wskazuje na potrzebę stałej autopromocji oraz na świadomość bycia wystawionym na podglądanie przez innych użytkowników ${ }^{16}$. Współczesne pokolenie internautów, publikując w sieci swoje zdjęcia, filmy z udziałem bliskich i przyjaciół, opowiadając o swoich sukcesach i porażkach, z własnej woli decyduje się na brak prywatności. Nowoczesne techniki multimedialne oferują coraz większe możliwości. Obrazy oglądane w sieci to zarówno zdjęcia nieruchome, jak i ruchome, dostarczone przez kamery, a do tego dostosowane do gustu odbiorcy, który może samodzielnie wybierać, co chce zobaczyć.

Poprzez komputerowy interfejs może on sterować kamerami, zmieniając ich kąt nachylenia i kierunek inwigilacji, a często również dokonywać zbliżeń na konkretny obiekt lub regulować ostrość wyrazu ${ }^{17}$.

Zdaje się jednak, że szczęśliwie nadal w mediosferze medialnych ekshibicjonistów jest mniej niż osób zawzięcie strzegących prywatności własnej i swoich najbliższych. Dlatego zdaniem Zygmunta Baumana ${ }^{18}$ współcześnie można już nawet mówić o syndromie „oblężonej twierdzy”, pojawiającym się u wielu osób publicznych. Syndrom ów sprzyja silnej polaryzacji społeczeństwa - jedni, należący do mniejszości, a powszechnie rozpoznawani, robią wiele, by odseparować się od większości tzw. przeciętnych obywateli. Ci drudzy zaś z niecierpliwością oczekują na coraz nowsze, atrakcyjniejsze newsy penetrujące życie tych pierwszych. Media natomiast zrobią naprawdę wiele, by usatysfakcjonować swoich odbiorców. Dlatego Bauman, posługując się metaforą tzw. synopticonu, sugerował, że osoby publiczne muszą się pogodzić z nieprzerwaną inwigilacją ich prywatności, ponieważ proces synopticonu traktuje podglądanego człowieka (np. aktora, piosenkarza, polityka, sportowca, dziennikarza itp.) jako przedmiot obserwacji, której „masy” dokonują na pojedynczych reprezentantach swojego gatunku, nie widząc w tym nic niestosownego ${ }^{19}$.

15 Por. A. Koziński, M. Zaczyński, Uzależnieni od tabloidów, „Wprost” 2005, nr 44, s. 68-71.

16 Por. M. Kołodziejczyk, Wielkie ucho, wielkie oko, „Polityka” 2007, nr 37, s. 19.

17 A. Ogonowska, Voyeuryzm telewizyjny Między ontologia telewizji a rzeczywistościa telewidza, Kraków 2006, s. 94.

18 Por. Z. Bauman, Globalizacja, dz. cyt., s. 9-10.

19 Por. W. Godzic, Telewizja i jej gatunki po „Wielkim Bracie”, Kraków 2004, s. 273-274. 
Współczesny konsument mediów od najmłodszych lat przyzwyczajany jest do nieprzerwanego obcowania z obrazami; dzieje się tak za pośrednictwem telewizji, Internetu, gier komputerowych, skondensowanych przekazów wiadomości, trendu wizualizacji prasy. W wyniku tak przeprowadzonego procesu socjalizacji dzisiejszy odbiorca mediów, szczególnie ten z młodszego pokolenia, wykazuje stałe zainteresowanie życiem innych, ale obcych sobie osób, które wynika zarówno z atrakcyjności samej czynności, jak i z wyuczonego nawyku podglądania.

\section{Podsumowanie}

Niezaspokojona potrzeba podglądania innych ludzi, powierzchowność więzi i przyjaźni, migracje, częste zmiany miejsc zamieszkania, pracy, wykonywanych zawodów są efektem współczesnych przemian obyczajowych, kulturowych i społecznych. Progresywna wizualizacja mediów, jak też coraz większe znaczenie mediów wirtualnych staje się faktem, od którego nie ma odwrotu. Wiedzą o tym zarówno medioznawcy, kulturoznawcy, socjologowie, jak też i sami dziennikarze. Kwestią dyskusyjną jest to, jak owa wiedza zostanie wykorzystana w praktyce. Odpowiedź zapewne przyniesie kolejna dekada XXI w.

\section{BIBLIOGRAFA}

Aldridge, A. (2006). Konsumpcja. Warszawa: Wydawnictwo Sic!

Bauer, Z. (2009). „Twój gtos w twoim domu”: cztery typy tabloidyzacji. Referat wygłoszony na konferencji naukowej pt. Oblicza komunikacji. Jezyk i kultura tabloidów, 29-30.06, zorganizowanej przez Uniwersytet Wrocławski.

Bauman, Z. (2000a). Globalizacja. Warszawa: PIW.

Bauman, Z. (2000b). Ponowoczesność jako źródto cierpień. Warszawa: Wydawnictwo Sic!

Białek-Szwed, O. (2012). Voyeuryzm medialny w kontekście wspótczesnej prasy $w$ Polsce. Toruń: Wydawnictwo Adam Marszałek.

Godzic, W. (2004). Telewizja i jej gatunki po „Wielkim Bracie”. Kraków: Wydawnictwo Universitas.

Goffman, E. (2000). Cztowiek $w$ teatrze zycia codziennego. Warszawa: Wydawnictwo KR.

Kloch, Z. (2006). Odmiany dyskursu. Semiotyka życia publicznego po 1989 roku. Wrocław: Wydawnictwo Uniwersytetu Wrocławskiego.

Kluszczyński, R.W. (2001). Społeczeństwo informacyjne. Cyberkultura. Sztuka multimediów. Kraków: Wydawnictwo Rabid. 
Kołodziejczyk, M. (2007). Wielkie ucho, wielkie oko. Polityka, 37.

Konik, R. (2003). Eco-Logia kultury masowej. Przewodnik po kulturze masowej $w$ oparciu o estetyke Umberto Eco. Wrocław: Oficyna Wydawnicza Arboretum.

Kowalska, J. (2001). Nudni i upokorzeni. Rozmowa z prof. M. Szpakowską. Gazeta Wyborcza, 65.

Koziński, A. i Zaczyński, M. (2005). Uzależnieni od tabloidów. Wprost, 44.

Miczka, T. (2005). Kultura w stylu KISS. Pierwsze, czyli proste - Keep it Simple, stupie! Nowe Media - Nowe w Mediach, t. I.

Morawski, S. (2003). Obraz kultury na przełomie wieków. W: M.A. Potocka (red.), Postmodernizm. Kraków: Wydawnictwo Inter Esse.

Ogonowska, A. (2006). Voyeuryzm telewizyjny. Między ontologia telewizji a rzeczywistością telewidza. Kraków: Wydawnictwo Naukowe Akademii Pedagogicznej w Krakowie.

Pisarek, W. (red.) (2006). Stownik terminologii medialnej. Kraków: Wydawnictwo Universitas.

Polański, E. (red.) (2006). Wielki Stownik Ortograficzny PWN. Warszawa: WN PWN.

Sulima, R. (2001). Oko Wielkiego Brata. W: W. Godzic (red.), Podglad Wielkiego Brata. Kraków: Wydawnictwo Universitas.

Wojciszke, B. i Baryła, B. (2001). Podglądanie zamiast, przed i po. Charakte$r y, 5$.

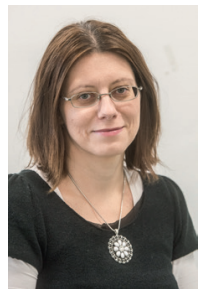

Olga Białek-Szwed - magister filologii polskiej (UMCS Lublin), absolwentka Podyplomowego Studium Dziennikarstwa (Uniwersytet Gdański), doktor nauk humanistycznych w zakresie nauk o polityce (UMCS). Adiunkt w Katedrze Języka Mediów i Komunikacji Społecznej w Instytucie Dziennikarstwa i Zarządzania Wydziału Nauk Społecznych KUL. Zainteresowania naukowe: współczesna prasa masowa, tabloidyzacja prasy, voyeuryzm i ekshibicjonizm medialny, turpizm i naturalizm we współczesnej prasie masowej, paradygmat kobiety we współczesnych mediach. Leksyka we współczesnej prasie socjolekty i profesjolekty, agresja językowa. 